\section{Identification of Sweetpotato Cultivars Using Isozyme Analysis}

\author{
Larry S. Kennedy and Paul G. Thompson \\ Department of Horticulture, P.O. Drawer T, Mississippi State, \\ MS 39762
}

Additional index words. Ipomoea batatas, enzyme, electrophoresis

Abstract. The enzymes alcohol dehydrogenase, diaphorase, esterase, glutamate dehydrogenase, glucosephosphate isomerase, isocitrate dehydrogenase, malate dehydrogenase, malic enzyme, 6-phosphogluconate dehydrogenase, phosphoglucomutase, shikimate dehydrogenase, and xanthine dehydrogenase were analyzed by starch gel electrophoresis of leaf tissue from nine sweetpotato [Ipomoea batatas (L.) Lam.] cultivars. Bands of most enzymes were well-defined. Polymorphisms were found in nine enzymes, and cultivars were identified by comparing polymorphisms.
Isozyme application was outlined by Pierce and Brewbaker (1973) and included cultivar identification. Isozyme analysis has subsequently been reported for cultivar identification for several clonally propagated species including apple. (Weeden and Lamb, 1985), Camellia japonica (Wendel and Parks, 1983), pineapple (Dewaid et al., 1988), raspberry (Cousineau and Donnelly, 1989), and strawberry (Bringhurst et al., 1981). Biochemical markers offer a more precise method for distinguishing cultivars than morphological characteristics and promise to be valuable supplements for patent identifications (Moore and Collins, 1983). In addition, isozymes can be used to study within-population genetic variability and relationships among clones.

Isozyme studies on sweetpotato have been limited and few enzymes have been examined. Variation in esterase (Kokubuand Hirai, 1978) and peroxidase (Kokubu and Maeda, 1978; Kokubu and Nokakawaji, 1982) isozymes was found among sweetpotato cultivars and related wild species using horizontal thin layer agar gel electrophoresis. Xue et al. (1988) reported interspecific diversity between sweetpotato and related wild species inperoxidase isozymes determined bypolyacryiamide gel electrophoresis. Our purpose was to determine if starch gel electrophoresis could be used effectively to observe isozyme variability of 12 enzyme systems in sweetpotato for cultivar identification and indication of common ancestry among cultivars. Since we found no previous work with starch gel electrophoresis on sweetpotato, electrophoretic procedures and techniques used on other species (Tanksley and Orton, 1983) were adapted for use on sweetpotato. 'Regal', 'Southern Delite', 'Travis', 'Vardaman', and 'W216' sweetpotatoes were compared for isozyme banding patterns. Plants

Recieved for publication 19 June 1990. Miss. Agricultural and Forestry Experiment Station Article no. J-7448. The cost of puhlishing this paper was defrayed in part by the payment $\mathrm{f}$ page charges. Under postal regulations, this paper therefore must be hereby marked advertisement solely to indicate this fact.
'Centennial', 'Jasper', 'Jewel', 'MD708', were used in preparing, electrophoresing, and staining the gels.

Plant materials consisted of two 25-mm plants of each cultivar transplanted to pots and grown in a greenhouse. Analyses were started 4 weeks after transplanting and continued for 3 months. No variation in banding patterns for any enzyme was observed due to differences in plant age. Immature leaves, 5 to $10 \mathrm{~mm}$ long, from each of the two plants of each cultivar were collected in early morning as source material for enzyme extraction. About $300 \mathrm{mg}$ of leaf tissue was homogenized in $2 \mathrm{ml}$ of an extraction buffer solution consisting of $0.1 \mathrm{M}$ Tris, $32.5 \mathrm{~mm}$ reduced glutathione, $14 \mathrm{~mm}$ beta-mercaptoethanol and $200 \mathrm{mg}$ of polyvinylpolypyrrolidone. The macerated samples were then centrifuged at $4 \mathrm{C}$ for $15 \mathrm{~min}$ at $10,000 \times \mathrm{g}$. The supernatant was frozen quickly at $-20 \mathrm{C}$ for future use. Banding resolution of frozen extracts after 1 week was compared with fresh extracts and no difference was observed. Since activity of some enzymes is known to diminish with freezing time (Wendel and Weeden, 1989), samples older than 1 week were discarded.

Two buffer systems were effective in separating isozymes of sweetpotato. Buffer system A (Cordy et al., 1983) was a discontinuous system that clearly defined DIA, EST, GDH, GPI, ME, PGM, and XDH, and system B (Shaw and Prasad, 1970) was a continuous system that best elucidated banding of $\mathrm{ADH}, \mathrm{IDH}, \mathrm{MDH}$, 6-PGD, and SKDH (Table 1). A $13.5 \%$ (w/v) starch gel was used for system A and a 13\% (w/v) starch gel was most effective for system B. A constant current of $40 \mathrm{~mA}$ was applied to system A for $5 \mathrm{~h}$ and $30 \mathrm{~mA}$ to system B for $3 \mathrm{~h}$. The staining solutions were described by Kennedy (1989). Electrophoretic analyses were repeated a minimum of three times for each enzyme after the optimum gel/staining system was determined.

Among the sweetpotato cultivars examined, the enzymes GDH, IDH, and $\mathrm{XDH}$ were not useful for cultivar identification be-

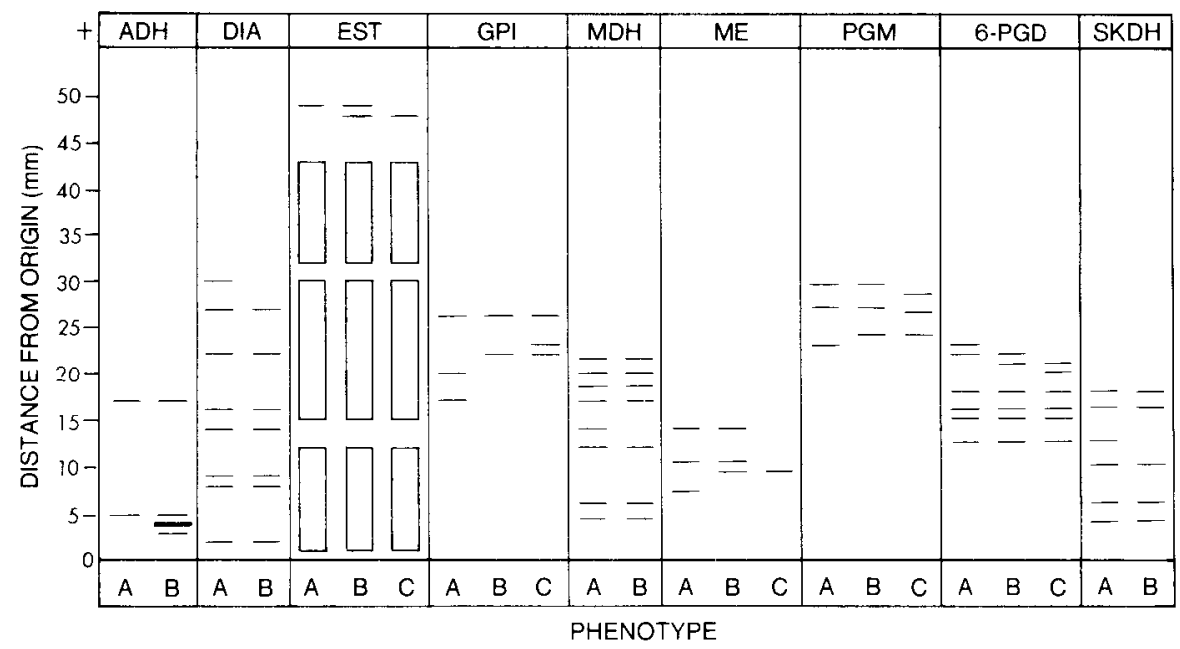

Fig. 1. Sweetpotato leaf isozyme phenotypes separated by starch gel electrophoresis. EST had three regions of dense banding with several bands each that appeared monomorphic. 
Table 1. Gel and electrode buffers used in starch gel clectrophorcsis for isozyme analysis of sweetpotato.

\begin{tabular}{|c|c|c|c|}
\hline $\begin{array}{l}\text { Buffer } \\
\text { system }\end{array}$ & Buffer type & $\mathrm{pH}$ & Chemical ingredient \\
\hline \multirow[t]{2}{*}{ A } & Electrode & 8.3 & $\begin{array}{l}0.19 \mathrm{M} \text { Boric acid } \\
0.04 \mathrm{M} \text { Lithium } \\
\text { hydroxide }\end{array}$ \\
\hline & $\begin{array}{l}\text { Gel ( } 9 \text { parts gel buffer: } \\
1 \text { part electrode buffer) }\end{array}$ & 8.3 & $\begin{array}{l}0.05 \mathrm{M} \text { Tris } \\
0.007 \mathrm{M} \text { Citric acid } \\
\text { (monohydrate) }\end{array}$ \\
\hline \multirow[t]{2}{*}{ B } & Elcctrode & 7.0 & $\begin{array}{l}0.135 \mathrm{M} \text { Tris } \\
0.043 \mathrm{M} \text { Citric acid } \\
\text { (monohydrate) }\end{array}$ \\
\hline & $\begin{array}{l}\text { Gel (1:14 dilution } \\
\text { of electrode buffer) }\end{array}$ & 7.0 & \\
\hline
\end{tabular}

Table 2. Enzyme phenotypes of swectpotato cultivars.

\begin{tabular}{|c|c|c|c|c|c|c|c|c|c|}
\hline \multirow[b]{2}{*}{ Cultivar } & \multicolumn{9}{|c|}{ Enzyme $^{z}$} \\
\hline & $\mathrm{ADH}$ & DIA & EST & GPI & $\mathrm{MDH}$ & $\mathrm{ME}$ & 6-PGD & PGM & $\overline{\mathrm{SKDH}}$ \\
\hline Centennial & A & B & $\mathrm{A}$ & A & $B$ & B & $B$ & B & $B$ \\
\hline Jasper & $\mathrm{B}$ & $\mathrm{B}$ & $\mathrm{B}$ & $\mathrm{B}$ & B & $\mathrm{C}$ & B & B & B \\
\hline Jewel & $\mathrm{A}$ & $\mathrm{A}$ & $\mathrm{A}$ & A & $B$ & $\mathrm{C}$ & $\mathrm{C}$ & C & $\mathrm{B}$ \\
\hline MD 708 & A & $\mathrm{B}$ & $\mathrm{B}$ & $\mathrm{B}$ & A & $\mathrm{A}$ & A & $\mathrm{C}$ & $\mathrm{A}$ \\
\hline Regal & A & A & $\mathrm{B}$ & $\mathrm{B}$ & A & C & A & $\mathrm{A}$ & $\mathrm{B}$ \\
\hline Southern Delite & A & $\mathrm{B}$ & $\mathrm{B}$ & $\mathrm{C}$ & B & $\mathrm{C}$ & $\mathrm{C}$ & B & $\mathrm{B}$ \\
\hline Travis & B & A & $\mathrm{B}$ & B & B & $\mathrm{C}$ & $\mathrm{C}$ & B & B \\
\hline Vardaman & A & B & $\mathrm{C}$ & B & B & B & B & B & B \\
\hline W216 & A & $\mathrm{B}$ & $\mathrm{B}$ & $\mathrm{B}$ & $\mathrm{A}$ & $\mathrm{C}$ & B & B & A \\
\hline
\end{tabular}

${ }^{z}$ See Fig. 1 for phenotypes $\mathrm{A}, \mathrm{B}$, and $\mathrm{C}$ of different enzymes.

Table 3. Origin of swectpotato cultivars characterized by isozyme analysis.

\begin{tabular}{ll}
\hline \hline Cultivar & Parent(s) ${ }^{2}$ and its origin \\
\hline Centennial & L5-130, polycross seedling out of \\
& Unit 1 Porto Rico $\times$ Pelican Processor \\
Jaspar and Travis & L3-217, polycross scedling out of \\
& LO-99, polycross seedling out of \\
& {$[($ Mameyita $\times$ L4 -6$) \times$ (Pelican Processor } \\
& $\times$ Triumph)] \\
Jewel & Centcnnial $\times$ Nugget \\
MD-708 & Maryland polycross seedling \\
Regal and Southern Delite & W-99, polycross scedling out of SC-1166 \\
Vardaman & M97-4 X HM145 \\
W-216 & Resisto, polycross seedling out of W-56 \\
\hline
\end{tabular}

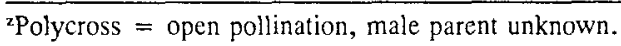

cause each enzyme showed only one band of equal mobility for all nine cultivars. However, each of the nine remaining enzyme systems had at least one polymorphic region (Fig. 1).

Two regions of activity were exhibited by $\mathrm{ADH}$. One was a fast-migrating, monomorphic zone and the other was a slowmigrating, polymorphic zone that included a single fast-banded and three-banded phenotypes. DIA had five regions of activity, and the fastest migrating one was polymorphic. The fastest migrating activity zone of EST was polymorphic, and the three phenotypes observed were fast, slow, and double-banded. Three additional groups of closely spaced bands identified for EST appeared monomorphic. GPI, MDH, ME, and SKDH produced five, eight, four and six bands, respectively, and each had a polymorphic region near the midrange of speed of migration. Each of three PGM phenotypes included three well-resolved bands, but regions of activity were difficult to interpret. The three phenotypes were distinguishable by differences in rate of migration lationships are: 'Centennial' is a parent of 'Jewel'; 'Jasper' and 'Travis' are half-sibs or full-sibs; and 'Regal' and 'Southern Delite' are half-sibs or full-sibs. The number of duplicate phenotypes for nine isozymes among related clones was similar to that among unrelated clones for 'Centennial'/ 'Jewel' and 'Regal'/'Southern Delite' (duplicate phenotypes: 'Centennial'/'Jewel' = 5 , average of 'Centennial' and 'Jewel' with all other cultivars $=4$; 'Regal' $/$ ' Southern Delite' $=4$, average 'Regal' and 'Southern Delite' with all others = 4), 'Jaspar' and 'Travis' had more duplicate phenotypes than the average of those cultivars with all others, seven vs. four, respectively.

Conclusions are not possible regarding isozymic determination of common ancestry since exact relationships among clones are not known.

In summary, the nine cultivars used in this study were separated by comparing banding patterns from five of nine polymorphic enzymes, indicating sufficient variability for separation of additional cul tivars. The observed variability will, therefore, provide a method for precisely identifying cultivars for patent purposes.

\section{Literature Cited}

Allison, M. L., G.R. Ammerman, J.O. Garner, H.L. flammett, C.C. Singletary, F.T. Withers, and H.D. Palmertree. 1981. Vardaman, a new early maturing sweetpotato for Mississippi. Miss. Agr. For. Expt. Sta. Info. Sheet 1305.

Arulsekar, S. and D.E. Parfitt. 1986. Isozyme analysis procedures for stone fruits, almond, grape, walnut, pistachio, and fig. HortScience 21:928-933.

Bringhurst, R. S., S. Arulsekar, J.F. Hancock, Jr., and V. Voth. 1981. Electrophoretic characterization of strawberry cultivars. J. Amer. Soc. Hort. Sci. 106:684-687.

Brewer, G.J. and C.F. Sing. 1970. An introduction to isozyme techniques. Academic, New York.

Cardy, B. J., C.W. Stuber, and M.M. Goodman. 1983. Techniques for starch gel electrophoresis of enzymes from maize (Zea mays L.) Inst. Stat. Mimeogr. Ser. 1317. North Carolina State Univ. Raleigh.

Cousineau, J.C. and D.J. Donnelly. 1989. identification of raspberry cultivars in vivo and vitro using isozyme analysis. HortSciencc 24:490492.

Dewald, M. G., G.A. Moore and W.B. Sherman. 1988. Identification of pineapple cultivars by isozyme genotypes. J. Amer. Soc. Hort. Sci. 113:935-938.

Hernandez, Teme P., R.J, Constantine, H. Hamrnett, W.J. Martin, C. Clark, L. Rolston. 1981 'Travis' sweet potato. HortScience 16:574.

Hernandez, Teme P., Travis P. Hernandez, R.J. Constantine, and W.J. Martin. 1974. Jasper: A soil rot-resistant sweetpotato variety. L. Agr. Expt. Sta. Circ. no. 100.

Jones, A. P.D. Dukes. J.M. Schalk. M.G. Hamilton, and R.A. Baumgardner. 1987. 'Southern Delite' sweet potato. HortScience 22:329-330.

Jones, A., P.D. Dokcs, J.M. Schalk, M.G. Hamilton, M.A. Mullen, R.A. Baumgardner, D. R. Paterson, and T.A. Boswell. 1983. 'Resisto' sweet potato. HortSciencc 18:251-252.

Jones, A., P.D, Dukes, J.M. Schalk, M.G. Hamilton, M.A. Mullen, R.A. Baumgardner, D.R. 
Paterson, and T.A. Boswell. 1985. 'Regal' sweet potato. HortScience20:781-782.

Kennedy, L.S. 1989. A study of isozyme variability and inheritance of sweet potato, Ipomoea batatas (L.) Lam., utilizing gel electrophoresis. MS Thesis, Mississippi State Univ., Mississippi State.

Kokubu, T. and M. Hirai. 1978. Variation of esterase isozymes in sweetpotato varieties. Memoirs Faculty Agr. Kagoshima Univ. 23:85-92.

Kokubu, T. and K. Maeda. 1978. Variation of peroxidase isozymes in sweetpotato varieties. Memoirs Faculty Agr. Kagoshima Univ. 23:77 84.

Kokubu, T. amd T. Nakakawaji. 1982. Variation of peroxidase isozymes in the wild related species of sweetpotato. Memoirs Faculty Agr. Kagoshima Univ. 18:69-74.

Miller, J. C., J.J. Mikell, T.P. Hernandez, and W.J. Martin. 1960. Centennial: A new sweetpotato variety. La. Agr. Expt. Sta. Circ. no. 63.
Moore, G. A.and G.B. Collins. 1983. New challenges confronting plant breeders, p. 25-51. In: S.D. Tanksley and T.J. Orton (eds.). Isozymes in plant genetics and breeding, part A. Elsevier, Amsterdam.

Pierce, L.C. and J. Brewbaker. 1973. Applications of isozyme analysis in horticultural science. HortScicncc 8:17-22.

Pope, D. T., L. W. Nielsen, and N, C. Miller. 1971. Jewel, a new sweet potato variety for North Carolina. N.C. Agr. Expt. Sta. Bul. 442.

Shaw, C.R. and R. Prasad. 1970. Starch gel electrophoresis of enzymes-a compilation of recipes. Biochem. Genet. 4:297-320.

Shields, C. R., T. J. Orton, and C. W. Stuber. 1983. An outline of general resource needs and procedures for the electrophoretic separation of active enzymes from plant tissues, p. 443468. In: S.D. Tanksley and T.J. Orton (eds.). Isozymes in plant genetics and breeding, part A. Elsevier, Amsterdam.
Tankskey, S.D. and T.J. Orton. 1983. Isozymes in plant genetics and breeding, part A. Elsevier, Amsterdam.

Vallejos, C.E. 1983. Enzyme activity staining, p. 469-516. In: S.D. Tanksley and T.J. Orton (eds.). Isozymes in plant genetics and breeding, part A. Elsevier, Amsterdam.

Weeden, N.F. and R.C. Lamb. 1985. Identification of apple cultivars by isozyme phenotypes. J. Amer. Soc. Hort. Sci. 110:509-515.

Wendel, J.F. and C.R. Parks. 1983. Cultivar identification in Camellia japonica L. using allozyme polymorphisms. J. Amer. Soc. Hort. Sci. 108:290-295.

Wendel, J.F. and N.F. Weeden. 1989. Visualization and interpretation of plant isozymes, p. 5-45. In: D.E. Soltis and P.S. Soltis (eds.). Isozymes in plant biology. Dioscorides, Portland, Ore.

Xue, Q. H., S.Y. Shi, A.M. Liu, and Q.H. Yi. 1988. Analysis of peroxidase isozymes of Ipomoea species. Chinese J. Genet. 15:41-48. 